\title{
"Laurus" by Eugene Vodolazkin in Polish Perception
}

\author{
Elzbieta Tyszkowska-Kasprzak* \\ University of Wroclaw \\ 1 Pl. Uniwersytecki, Wrocław, 50-137, Poland
}

Received 10.01.2017, received in revised form 18.08.2017, accepted 28.08.2017

The article examines the Polish readers' response to Eugene Vodolazkin's novel "Laurus" (published in Polish in 2015). To analyze this perception, the author has studied readers' opinions on the Internet and critical reviews. The Polish readers' response to the novel does not fit into Poland's current cultural policy towards Russia. While Russia is represented in Poland not in a good light, there has not been any negative or even low assessment of "Laurus". Most readers emphasize that the novel is understandable in Poland since Russians and Poles have the similar Slavic soul, the same emotionality, and akin worldviews.

Having compared the opinions of critics and readers, one can notice a significant difference. The reader seeks in the literary text what is specifically literary and does not regard the work in the light of aesthetics, but rather evaluate it using such categories as personal emotions and impressions. What is important there is satisfaction with the work read, identification with the character, and a chance to get carried away. In turn, critics do not account for the possibility to separate the artistic text from the public context and they explain the aesthetic material taking into account another cultural order.

Keywords: E. Vodolazkin, reader-response criticism, literary criticism.

DOI: 10.17516/1997-1370-0159.

Research area: philology.

\section{Introduction}

The question of the literary work existence in society is still open, but the fact that it is not confined to a single text is beyond any doubt. Along with the study of the work itself from the point of view of the text structure, its idea, the history of creation, intertextual ties, the historian of literature should grasp the connection between a literary text and its reader. The understanding of the historically conditioned public function of literature, the description of literary life in different epochs requires taking into consideration not only the existence of a literary work, but also its reception, since the text, being an aesthetic sign addressed to the reader, is subject to perception, interpretation, and evaluation (Jauss, 1986: 152-156).

As Felix Vodicka stated: "Evaluation presupposes the existence of certain criteria that are by no means constant, and therefore the work evaluation cannot remain constant and unchangeable. Since the evaluation criteria and

(C) Siberian Federal University. All rights reserved

* Corresponding author E-mail address: elzbieta.tyszkowska-kasprzak@uwr.edu.pl 
artistic values are subject to continuous changes in the historical process, the natural task of the literary historian is to capture these changes" (Vodicka, 1969: 273). This approach to the study of the literary process, which abides by not only the analysis of the texts themselves but also the communication caused by them, has been proposed by many researchers (Ehrismann, 1980, Mandelkow, 1980). Not just one work is a literary process component, but the whole literary space with this work as a core.

\section{Theoretical framework}

In the case of analyzing the perception of a literary text, it is first of all necessary to determine the quality and volume of materials that can become the research object in literary communication. The fact of the literary text perception is not given to a literary critic directly as compared to the very literary work. The communication act should be reproduced on the basis of facts that can be examined as evidence of perception. They are, as a rule, diverse and of different kinds.

Polish literary critic Michal Glowinski distinguishes five groups of evidence of the literary works perception. The first group covers statements (literary, paraliterary, critical), the theme of which was the literary text reading. The second group includes metaliterary reasoning, the theme of which is not the text perception. The way of understanding them is manifested indirectly, depending on the categories presented with the help of corresponding works (e.g., works on the literary theory or history). The next circle embraces the works referring to other literary texts by means of the structure, including pastiches, parodies, and stylization. The next group (transformations) is heterogeneous; it includes translations into other languages, paraphrases, and transcriptions into other forms of art. As the last type of perception Glowinski singles out sociological studies that represent statistics on the readership of the work as regards different social groups (Glowinski, 1988: 429-435).

Statements of criticism are often the only (and if not the most prominent) expressed readers' reaction. This criticism indicates that the work was perceived in a specific place and time. Among the many acts of perception through which the work functions in public circulation, the researchers have at their disposal only those few that are fixed in written utterances. For literary critics, they illustrate a whole gamut of readers' reactions to the artistic text. The appearance of at least one critical review makes a literary fact a three-part system: between the literary work and the readers' silent opinion, there is a recorded estimation, the evidence of reading taking place (Slawinski, 1992: 125-126).

Criticism in literary communication has two directions. The critics reproduce the process of the literary text perception, and in this sense these authors are recipients, but at the same time they offer readers a way of reading, and then the next critical authors act as addressers. Reasoning about literary works gives information about the realities of literary life (the activities of publishing houses, cultural policy, literary magazines, and websites), and about readers' expectations, their value systems, and aesthetic tastes.

In contemporary literary life, along with literary criticism, we deal with the readers' observations, placed, as a rule, on the Internet. In connection with broad access to the network, not only comments of professional critics appear there, but also the readers' remarks which very often influence readership preferences more than criticism. Comparing the opinions of critics and readers, one can notice a considerable difference. The reader seeks in the literary text what is specifically literary, and does not consider the work in the light of aesthetics, but rather in the 
light of personal emotions and impressions. For readers, it is important to enjoy reading the work, to identify with the character, to get distracted. The reader often finds in the author an ally who created an autotelic text. In turn, the critic does not allow for separating the artistic text from the public context, explaining the aesthetic material in the categories of another cultural order (Dybciak, 1979: 82-83).

\section{Statement of the problem}

Eugene Vodolazkin's novel "Laurus" was published in Poland in 2015 by The Publishing House "Zyski i Spolka" in the translation of Ewa Skorska, with the cover designed by Mariusz Kula (Wodolazkin, 2015). In the case of perception of a literary text in a foreign culture environment, there are two coinciding types of perception, since we have to do with the perception of translation. Since the translation itself is evidence of perception, it is possible to apply here a dual model of communication in which the author-addresser creates the first code perceived by the translator, who in turn makes up the second code perceived by the reader (Legezynska, 1998: 281-282).

Translation is a literary text created on the basis of another communication stratum with the help of another language and addressed to another reader. This addressee lives in a particular reality, in an original and geocultural space different from the author's one. In the course of translation, the translator interprets the text and looks for the stylistic equivalents in the target language that are appropriate, in his / her opinion. Numerous translations of some works testify to the multitude of possibilities of this interpretation. Fiction in the original language is a single, one-off utterance, while translation by nature is one of many possible utterances (Balcerzan, 2013: 103).

The problem of translating the novel "Laurus" into Polish requires an individual thorough analysis, but in brief, any reader can see that the translator coped quite well with the stylization of the work, because "Laurus" intertwines several language strata. As the author himself admitted, "In my novel, there are two types of consciousness: one medieval, the other one - modern. This is a rare case for modern literature, when not the author, but the narrator is able to move from one consciousness to another: that is, when he writes as a medieval person, and then as if 'straightens out' and casts a glance from the present. And in doing this I took advantage of different language elements among other things" (Vodolazkin, 2014). In the Polish translation, this transition is not so harsh and of a slightly different character than in the original text, as Church Slavonic is replaced by the language of the Bible translation into Polish. Unfortunately, the translation does not always capture those moments in which other styles and jargon are used, and often situations, where the author plays with style and sneers through speech, are reduced to a neutral language norm in the translation.

\section{Discussion}

Evidence of the Polish perception of "Laurus" can be divided into readers' reviews, which are usually published on the Internet, and professional reviews published by literary critics. Nowadays, non-professional critics-readers are a noteworthy and significant group of people interested in literature. They bring together online magazines on the topic of books read, write reviews on bookshops' websites, launch discussion communities, and compile book ratings (Maryl, 2015: 102-104). The opinion of such readers influences the popularity of books to a greater extent than the critics' reviews published in traditional journals.

The Polish reception of "Laurus" does not fit into the newest Poland's cultural policy in relation to Russia. While it is not customary in 
Poland to represent Russia in good light, there has not been any negative or even low evaluation of "Laurus". Most readers emphasize that the novel is understandable in Poland since Russians and Poles have the similar Slavic soul, the same emotionality and akin ways of seeing the world. In their statements about "Laurus" many authors define their attitude to Russian literature in general. Some claim that they read Russian classics since a cultural person is obliged to know Leo Tolstoy and Fyodor Dostoevsky (sometimes they only refer to the latter). Still, there are also those, who, strangely enough, admit that they have never read any Russian novels before. They just decided to try reading something new and are not disappointed.

Many of them associated their decision to read "Laurus" with its attractive cover, which depicts the face of a bearded old man. His wise eyes, the eyes of a man who lived and understood the meaning of life were found appealing; other readers admitted that the image itself caused an association with a monk, a hermit - a representative of another religion and culture.

Most of the statements on the subject of the novel contain "advertising" slogans in large print on the book cover. The first one is information that the novel was awarded the literary award "The Big Book" in 2013, which in fact does not give the Polish readers an idea of the level of this literature, as they are not aware of the rank of this award. The second slogan "the author is the Russian Umberto Eco" works on the readers' imagination. As Zbigniew Bauer noted, "The significance of the recommendation, especially in the field of culture, is next to none in Poland today. <...> The hierarchy of estimates can be constructed only on the basis of the method of clear comparisons" (Bauer, 2005: 234). But it must be stressed that this comparison with $U$. Eco is often commented on by the authors of the reviews, and there is no agreement between them on the matter. Some believe that Vodolazkin does not deserve such a comparison, others write that the comparison is completely justified, but there is also an opinion Vodolazkin does not need such a comparison, since his prose is completely original, and the only thing that unites both authors is historical time of action, but they reproduce medieval realities for different purposes.

Some reviews contain an attempt to determine the symbolism of the protagonist's wanderings. Unfortunately, most authors use for this purpose the publisher's slogan "a journey deep into the Russian soul". Only a few reviewers try to see in the character of the universal personality and his ability to sacrifice his life for the sake of other people.

It is interesting that many readers pay attention to stylization, which complements the epoch's image. Some do not seem to notice that, in fact, this opinion refers not so much to the original text of the novel as to the translation. But there are also those who underline that the perception of the novel in Polish is facilitated by the excellent translation of Ewa Skorska.

In most of the statements, readers focus on the universal values that make up the idea of the novel. Most often readers name the problems of the victim, the boundary between good and evil, the power of faith, and the difference between holiness and sinfulness. Many people notice that the human life journey, presented as a journey of the protagonist, goes beyond time.

Some reviewers refer to the interview given by Eugene Vodolazkin to the website "Voice of Russia". Usually, they quote two fragments from Vodolazkin's statements. The first one: "I wanted to tell about a person capable of sacrifice. Not some great one-time sacrifice, for which a minute of ecstasy is enough, but a daily, hourly life of sacrifice. I wanted to oppose something else to the cult of success that prevails in modern society". 
The second one: "The hero grew out of dozens of such people who existed in Ancient Rus. There is no prototype. This is a hero of ancient Russian hagiography, Old Russian legends, chronicles, chronographs. All of them merged into my Laurus and became his literary ancestors" (Bolocka, 2013). The first fragment concerns the main idea of the novel, which is discerned by the Polish readers. The second part of the statement is given to confirm the opinion that the protagonist has his own prototype in history. This question is asked by many readers. They say that they perceived the work as a literary version of the life of one holy healer, and only Vodolazkin's remark clarified the essence of the protagonist's image.

Having looked through all the readers' comments, I found only two reproaches to Vodolazkin, but they were conditioned by the incompetence of evaluators who neither noticed nor recognized the novel's intertextuality. This is due to the fact that the Polish reader does not know Russian hagiography. For example, Alexander Kush, who highly appreciates Vodolazkin's work, is disappointed only by the fact that the style of the novel is completely devoid of emotions, which, in his opinion, makes the characters "paper" ones (Kusz, 2015). In turn, Mateusz Cyra writes on the website "The Voice of Culture" that the last stage of the protagonist's life is presented too briefly, and he had a feeling that the author was in a hurry with the end of the book, while he could have written about a hundred pages more (Cyra, 2015).

These misunderstandings arise from the lack of literary competence. The work of literature can be called a cultural object, whose meaning is realized through interpretation, and this meaning to a greater or lesser extent determines the principles of cultural interpretation, which are contained, among other things, in the interpreter's knowledge (Kmita, 1987: 62). The lack of knowledge that we meet in the above-mentioned utterances violates literary communication and leads to erroneous and wrong judgments.

The second group of reviews on "Laurus" is formed by the opinions of professional literary scholars who know both Russian literature and Russian culture. The authors of the first quote on the book cover are Wiktoria and Rene Sliwowscy, well-known Polish philologists specializing in Russian literature, literary critics, and translators of Russian literature. Their text is of an advertising nature, and like other quotes on the cover, it aims to persuade a potential reader to buy and read the book (Szczesniak, 2011: 30). At the very beginning, Sliwowscy accentuate that the novel is addressed not only to religious people, in spite of the fact that the main character is a holy fool and healer. W. and R. Sliwowscy define the main idea of the novel as the struggle of good against evil, which has manifested itself in different forms in all epochs. The authors also draw attention to the remarkable composition of the story and the Polish translation, which is assessed very highly (Sliwowscy, 2015, cover).

As an example of typical journal reviews by Polish authors I will mention reviews by Bozena Witowicz (Witowicz, 2015) and Katarzyna Syska (Syska, 2016). The former is a Warsaw philologist specializing in Russian literature, who published her reflections of Vodolazkin's "Laurus" in the monthly news publication "New Books". She pays attention to the novel's cognitive merits, underscores that the writer put in his work much information about life in Russia in the Middle Ages: about customs, mores, medicine, the system of education, and worldview. She also distinguishes issues of ethics, philosophy, and religion, such as the problems of freedom, charity, redemption, and mercy. According to Witowicz, the main problem that is the common thread throughout the narrative is whether one can live a life instead of another person (Witowicz, 2015: 33). 
The critic also points out the compositional features of the work; she believes that four parts of the novel, stylized as Biblical books, reflect the four protagonist's changes. Witowicz dwells on the problem of the "Laurus" intertextuality, referring to some of its sources - apocrypha, the lives of saints, indicating the stylization of the genre of pilgrimage to the Holy Land and "The Journey Beyond Three Seas" by Afanasy Nikitin. Witowicz focuses on the problem of time in the novel, emphasizing that although the hero is placed in a crucial epoch for mankind, the novel itself is timeless. She reproaches Vodolazkin in that turning to modernity causes the negative impressions of readers, as today's knowledge does not coincide with the truth of the novel, and information given from the present point does not contribute anything to the narrated story and even destroys the narrative. In conclusion, the critic outlines the difference between Vodolazkin's novel and the works of other Russian postmodernists. The difference involves invoking the spirituality of the protagonist and the humanity apotheosis (Witowicz, 2015: 33).

Katarzyna Syska, who works at the Jagiellonian University, reviews the novel "Laurus" in more detail and stresses that in Russia it was highly appreciated by both critics and readers. In her opinion, it can be attributed to Russian classical literature. The critic gives heed to different layers of the work and the different ways of reading it. She argues that "Laurus" can be read as a love-adventure novel, narrating about the main hero's way to the redemption of sins. The work can also be perceived as a historical novel in which Vodolazkin, an outstanding connoisseur of the Middle Ages in Russia, created a convincing way of life in the 15th century Russian north. Another way of reading is the approach to the text as a theological one reflecting the Orthodox spirituality (both folk and monastic) in the second half of the 15th century. The story of the protagonist can demonstrate reasoning on the nature of God, the afterlife, and spiritual perfection. Syska thinks that the most important layer of the novel's perception is the philosophical layer, in which the problem of time is brought to the forefront. In her opinion, the main idea of this level is the negation of time as a linear phenomenon, the erasure of boundaries between epochs, the recurrence of time, which leads to the idea of the man existence not only in this very epoch but in eternity. The critic describes that the author implements this idea also through some linguistic means, mixing different styles. To sum up this analysis, the Syska comes to the conclusion that all these layers create a multivocal novel, both mystical and ironic, sublime and carnival (Syska, 2016: 152).

Syska assumes that the popularity of "Laurus" in Russia can be associated with the popularity of Orthodox mysticism, which is directly connected to the success of Pavel Lungin's film "The Island" and the collection of stories "Everyday Saints and Other Saints" by Bishop Tikhon Shevkunov. Moreover, Syska points out to the weak points of the Polish translation and ends her evaluation by judging that the Polish reader received a very good novel instead of a perfect one (Syska, 2016: 153).

\section{Conclusion}

In general, Polish readers and critics appreciated "Laurus" very highly. They emphasized the detailed reproduction of the Middle Ages realities and at the same time the universal meaning of the work. Unfortunately, all these factors did not boost Vodolazkin's popularity in Poland, apparently, only because the book's publication was not accompanied by a proper advertising campaign. In May 2015, the author was invited to the international book fair, 
which was held in Warsaw, but since this event was not discussed in the Polish media, the visit was of local significance only.

Undoubtedly, "Laurus" made a great impression on the Polish literary critics specializing in Russian literature, who began to analyze the novel, but their work has not yet appeared due to the lengthy publishing process. The scientific interest in Vodolazkin's writings is proved by the fact that in 2018 the second conference of the series "Prominent Russian Writers of Contemporary Literature" (to be held at the Jagiellonian University) will be dedicated to his works.

\section{References}

Balcerzan, E. (2013). Poetics of artistic translation [Poetyka przekładu artystycznego], In Polska mysl przekladoznawcza, Kraków, Wydawnictwo Uniwersytetu Jagiellonskiego, 103-118.

Bauer, Z. (2005). Do we need criticism in the era of postmodernism? [Coz po krytyce w czasach postmodernizmu?], In Annales Universitatis Paedagogicae Cracoviensis, Folia 26, Studia Historicolitteraria,5, 233-243.

Bolocka, R. (2013). "Laurus" received the Prize [Nagrode otrzymal "Laurus"], In Glos Rosji 2.12.2013, available at: https://pl.sputniknews.com/polish.ruvr.ru/2013_12_02/Nagrode-otrzymalLaur/

Cyra, M. (2015). “Laurus” by Eugene Vodolazkin [“Laurus” Jewgienija Wodołazkina], available at: http://www.gloskultury.pl/wieloglosem-o-laur-jewgienij-wodolazkin/

Dybciak, K. (1979). The nature and structure of literary criticism [Istota i struktura krytyki literackiej], In Teksty: teoria literatury, krytyka, interpretacja, 6, 70-95.

Ehrismann, O. (1980). Thesis on the writing of the history of reception [Tezy o pisaniu historii recepcji], In Pamiętnik Literacki, 1, 309-318.

Glowinski, M. (1988). Testimonies and styles of reception [Swiadectwa i style odbioru], In Problemy teorii literatury, 3, Wroclaw, Ossolineum, 428-443.

Jauss, H.R. (1986). Paradigm shifts in literary studies [Zmiany paradygmatów w nauce o literaturze], In Wspótczesna myśl literaturoznawcza w Republice Federalnej Niemiec. Warszawa, Czytelnik, 151-162.

Kmita, J. (1987). Understanding in the process of reception of a literary work [Rozumienie w procesie odbioru dziela literackiego], In Problemy teorii literatury, 3, Wroclaw, Ossolineum, 58-74.

Kusz, A. (2015). A journey into the Russian soul? [Podroż w głab rosyjskiej duszy?], available at: http://szortal.com/node/7664

Legeżyńska, A. (1998). Translator, the second author [Tłumacz, czyli drugi autor], In Problemy teorii literatury, 4, Wrocław, Ossolineum, 281-295.

Mandelkow, K.R.(1980). History of interaction and its problems [Problemy historii oddzialywania], In Pamietnik Literacki, 1, 245-258.

Maryl, M. (2015). A literary life in the network [Zycie literackie w sieci], Warszawa, Fundacja Akademia Humanistyczna, Instytut Badan Literackich PAN, 469 p.

Slawinski, J. (1992). Literary criticism as the subject of literary history [Krytyka literacka jako przedmiot badan historycznoliterackich], In Proby teoretyczno literackie, Warszawa, PEN, 115-137.

Syska, K. (2016). Postmodern hagiography [Postmodernistyczna hagiografia], In Nowa Europa Wschodnia, 2, 151-153. 
Szczesniak, K. (2011). A book's cover and wrapper as an object of interdisciplinary researches [Okladka i obwoluta książki jako przedmiot badań interdyscyplinarnych], In Torunskie studia bibliologiczne, 2, 29-41.

Sliwowscy, W.R. (2015). A note on the cover [Notatka na okłldce], In Wodolazkin, J. Laur, Poznań, Zysk i S-ka Wydawnictwo.

Vodicka, F. (1969). History of literature. Its problems and tasks [Historia literatury. Jej problemy i zadania], In Pamietnik Literacki, 3, 257-286.

Vodolazkin, E. (2014). Chelovek v centre literatury [The Man in the Centre of Literature], In Pravoslave i mir [The Eastern Orthodox Church and the World], available at: http://www.pravmir.ru/ chelovek-v-centre-literatury/

Witowicz, B. (2015). The Middle Ages and postmodernism [Średniowiecze i postmodernizm], In Nowe Ksiązki, 12, 33.

Wodolazkin, J. (2015). Laur. Poznan, Zysk i S-ka Wydawnictwo, 254 p.

\section{«Лавр» Евгения Водолазкина}

\section{В Польском Восприятии}

\section{Э. Тышковска-Каспшак}

Вроилавский университет

Польша, 50-137, Вроилав, Университетская пл., 1

В статье прослеживается восприятие в Польше романа Евгения Водолазкина «Лавр», который был издан в польском переводе в 2015 г.

Как свидетельства восприятия анализируются высказывания читателей, помещенные в Интернете, и отзывы литературной критики. Отзывы польских читателей и критиков на тему романа Евгения Водолазкина не вписываются в новейшую культурную политику Польши по отношению к России. В то время как Россию не представляют в Польше в хорошем освещении, не появилась ни одна отрицательная или даже низкая оценка «Лавра». Большинство читателей подчеркивают, что роман понятен в Польще, так как у русских и поляков та же славянская душа, та же эмоциональность и сходный способ видения мира.

Сравнивая мнения критиков и читателей, можно заметить существенную разнииу. Читатель ищет в художественном тексте то, что специфически литературно, причем не рассматривает произведение в категориях эстетики, но - в категориях личных эмочий, впечатлений. Для него важно получить удовольствие при чтении произведения, отождествиться с персонажем, увлечься. В свою очередь, критик не допускает возможности отделять художественный текст от общественного контекста, объясняя эстетический материал в категориях другого культурного порядка.

Ключевые слова: Е. Водолазкин, восприятие литературного текста, литературная критика.

Научная специальность: 10.00.00 - филологические науки. 